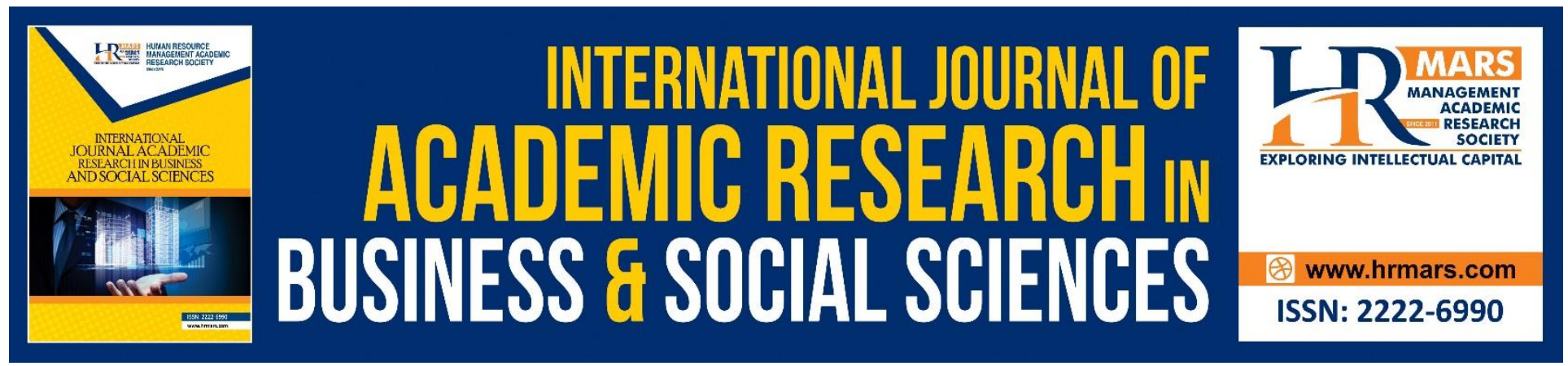

\title{
Ethics of Football Watching According to Islam
}

\author{
Basri Ibrahim, Muhammad Ammar Firhan
}

To Link this Article: http://dx.doi.org/10.6007/IJARBSS/v9-i3/5714

DOI: $\quad 10.6007 /$ IJARBSS/v9-i3/5714

Received: 07 Feb 2019, Revised: 29 March 2019, Accepted: 06 April 2019

Published Online: 12 April 2019

In-Text Citation: (Ibrahim \& Firhan, 2019)

To Cite this Article: Ibrahim, B., \& Firhan, M. A. (2019). Ethics of Football Watching According to Islam. International Journal of Academic Research in Business and Social Sciences, 9(3), 532-545.

\section{Copyright: (C) 2019 The Author(s)}

Published by Human Resource Management Academic Research Society (www.hrmars.com)

This article is published under the Creative Commons Attribution (CC BY 4.0) license. Anyone may reproduce, distribute, translate and create derivative works of this article (for both commercial and non-commercial purposes), subject to full attribution to the original publication and authors. The full terms of this license may be seen at: http://creativecommons.org/licences/by/4.0/legalcode

Vol. 9, No. 3, 2019, Pg. 532 - 545

Full Terms \& Conditions of access and use can be found at http://hrmars.com/index.php/pages/detail/publication-ethics 


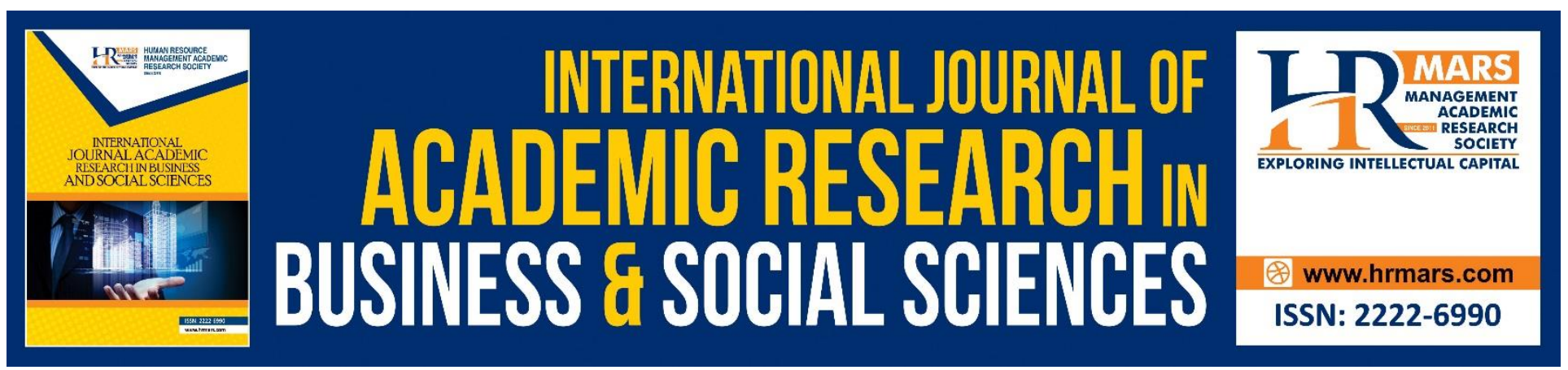

\title{
Ethics of Football Watching According to Islam
}

\author{
${ }^{1}$ Basri lbrahim, ${ }^{2}$ Muhammad Ammar Firhan \\ ${ }^{1}$ Global Wisdom Academy, Universiti Islam Malaysia, Cyberjaya, Malaysia/ Faculty Of Islamic \\ Contemporary Studies, Universiti Sultan Zainal Abidin, Terengganu, Malaysia. \\ ${ }^{2}$ Global Wisdom Academy, Universiti Islam Malaysia, Cyberjaya, Malaysia.
}

Corresponding Author:drbasr67@gmail.com.

\section{Abstract}

Football game has become a favourite game throughout the world including among Muslim countries. It does not just involve matches at the national level, but also at the international level. Nevertheless, frequently, football match is contaminated with unwanted incidents such as riot, quarrel, damage of public property, supporters raiding into the play field, hitting the players, supporters of opponent team and others, especially in Malaysia. As a result, damage happens to property of government and public, injury to the supporters and players and pollution to image of supporters and certain state football team. With regard to that, this article is brought upon aiming to explain on the ethics of football watching according to Islam to avoid damage to the property of government and public, injury, fine payment by certain team and pollution to image of supporters and football players. Method of this writing was based on qualitative study. Data were collected based on document analysis by referring to nooks regarding tafsir (Quranic interpretation), sunnah (Prophet's traditions), classical figh books, contemporary fiqh, current fatwas and opinions of contemporary Islamic scholars from various countries. Data collected were analysed and commented through inductive, deductive and comparative methods to gain appropriate result in alignment with the determined objective. This study found that ethics of football watching involve absence of swearing and utterance of filthy words, no damage to public properties, no insulting, backbiting or defaming and degrading of others, no disposal of eye-irritating and polluting object, no show of extremely sad character and face and no screaming, whistling, dancing and jigging.

Keywords: Game, Football, Sunnah, Fiqah, Watching

\section{Introduction}

Element closely related to football is the football supporter. Every football game must be attended by spectators which usually act as supporters for the competing team, even though in a small number. Watching football game is a favourite activity by Malaysian people. Moreover, football match is not silent from needing spectators which usually consist of supporters from both competing teams, either spectators at home or stadium. It can be seen every time when football match is held in our country either at the level of premier league or Football Association (FA) cup. 
For the time being, football game does not only become the number one sport in our country but also at the national level. However, reactions from a few of the spectators for this sport are always covered by the media. Without realising, the pattern of their reactions picture the identity and spirit of a particular community. Nevertheless, in context of our country, football sport is always contaminated by incidents originating from embarrassing spectators especially from the states in East Coast of Malaysian Peninsular, and at the same time visualise the lack of attitude and manner of the community in which majority of it are Muslims. These incidents are caused by dissatisfied spectators to several aspects regarding the quality of performance from the supported team, opponent team, referee, linesmen, goalkeeper and others, The question rising is what are ethics of football watching that must followed by every Muslim football spectators?

The aim of this article to be put forward is is to explain on the ethics of football watching either at the stadium or home. These ethics are important to produce highly-civilised football spectators, avoid damage of public property and protect the image of Muslim community from being tarnished by the irrelevant actions that they do during the watching of a certain football match. Some people opine that the watching of football match does not need particular ethics as it is a game that involves the custom and culture of a country. This kind of opinion is very difficult to be accepted in the current context as even it involves the custom and culture of a certain country, but according to the reality witnessed, football match has already become a match favoured by majority of the world population. It is not silent from any dissatisfaction of the spectators and damage of public property. These all need particular ethics to be brought upon to control the behavior of the spectators at the stadium of their own home.

Writings on football game and match have been produced by the contemporary scholars. Among them is Uthaimin (2017) commenting on the issue of football game through a website of question and answer for Islamic fatwas which is http://fatwa.islamweb.net/fatwa, Yusoff (2015) in Journal of GEOGRAFIA Online TM Malaysian Journal of Society and Space 11 issue 13 (72 - 78) 72 on the misconducts among football spectators in Malaysia, al-Qalmuni (2011) in the work titled Kurrah al-Qadam Wa Akhawatuha. He talked about the history of football and the harms emerging from the football game itself. Salman (1998) commented in Kurrah al-Qadam Bayna al-Masalih Wa al-Mafasid al-Syar'iyyah on the football game and focused on the aspects of needs and harms emerging from the game. Al-Qaradawi (1996) elaborated on the game in his book al-Islam Wa al-Fan. In the book, he touched on the games generally without focusing on the football game only and the procedures regarding the football watching. The same subject was also touched by al-Qaradawi (2006) in his work Fiqh al-Lahwi wa al-Tarwih. However, the above writings and researches did not touch on comprehensive serious study on the ethics of football pictured in the form of fiqh for football watching that complies with the demand of Islamic teachings.

\section{Research Methodology}

This writing was based on qualitative study. Data were collected from documentation study by referring to books related to tafsir (Quranic interpretation), sunnah (Prophet's traditions), classical fiqh books, principles of Islamic jurisprudence, contemporary fiqh, current fatwas and opinions of contemporary Islamic scholars. The collected data were then analysed and explained through comparative method to obtain appropriate results complying with the set objective. 


\section{Findings}

Football game is included into the allowed action by some of contemporary scholars in their fatwa, as there is no evidence that prohibits it. According to fiqh method, the origin of a subject is harus (allowed), indeed it can also be categorised as 'encouraged to do' (muakkad) if the purpose is to strengthen the body, as sharia encourages so much to do something that can strengthen the body as a preparation to face jihad (religious fight).

\section{Scholars who Allow Football Watching}

Among the contemporary scholars who allow the watching of football game and match are:

a. Fatwa Committee of Saudia Arabia Goverment (al-Ghamidi 1429H:187).

b. Muhammad Salih Uthaimin (https://islamqa.info, 2010).

c. 'Abd al-Aziz bin 'Abdullah Ali al-Syeikh (http://www.ajurry.com, 2018).

d. Abdullah al-Faqih (http://www.ahlalhdeeth.com, 2018).

e. 'Ubaid bin Abdullah al-Jabiri (http://www.ajurry.com, 2018).

f. Muhammad Nasir al-Din al-Albani (http://www.ahlalhdeeth.com, 2018).

g. al-Qaradawi (2016:72-73).

\section{Conditions for Permission of Football Watching}

The above scholars who allow the watching of football match put conditions to be observed by the spectators either at the stadium, coffee shops or home, which are:

a. The watching does not prevent somebody performing the prayer, does not expose to players' aurat, and does not provoke any fight or hostility.

b. The watching does not void any obligation or leads to any forbidden action (al-Ghamidi, 1429H:187).

c. The watching does not cause any mockery and insult between the supporters of opposing team.

d. The watching does not lead to negligence of large sharia needs (al-Qaradawi, 2006:72-73).

e. The watching keeps someone to hold firmly onto good moral disposition and manner.

f. The watching does not make a person to become too fanatical to a certain team leading to hatred and hostility with the opponent team (http://www.ajurry.com, 2018).

\section{Reasons of Permitting the Watching of Football Game with Conditions}

Among the reasons posed by this group are: 
a. There is no authentic and concrete evidence forbidding the football watching neither from alQuran nor al-Sunnah, while the ruling of something as haram must be based on authentic and concrete evidence.

b. Football game is a game involving culture and custom of the community, in which the original ruling related to it is harus, until there is evidence forbidding it.

c. Many of the scholars who decide that the football watching is forbidden, do not refer to the football match itself, instead it relates to other factors either externally or internally.

d. Football match still does not create larger harm compared to the benefits obtained through it.

e. Football game and match have happened throughout the world including in Islamic countries where their scholars forbid the football game itself. Muslims would not agree to do something bad according to Islamic view.

\section{Ethics for Watching of Football Match}

Among the forms of ethics for watching of football match are:

\section{a. Does Not Glorify the Admired Person Fanatically}

It is not wrong to admire or idolise somebody due to a certain advantage that Allah SWT bestows upon him, as long as it is not done in extreme, leading to ignorance of sharia obligation or responsibility towards children, wife and family. In football either in the nation or at the international level, there are always players admired by the supporters. The portraits of the admired player are sometimes printed on the shirt, and sometimes hanged on the wall of home especially players included into superstar category at the international and national level.

Interest, compliment, and praise given must be in the moderate framework. In Islam, the most eligible human to be praised are the prophets and Messengers, as they fought with their life to bring hidayah and guidance from Allah SWT to human beings, so that they can live in the light of guidance. Among the main prophets to be praised and glorified is Prophet Muhammad SAW who is the seal of all Prophets. Prophet SAW is not just praised in the prayer of every Muslim either in obligatory or supplementary prayer, but even outside of the prayer especially when somebody utters his name SAW. However, he prohibited Muslims from praising him more than he taught. In a hadis narrated through Umar RA, explaining, Rasulullah SAW said;

$$
\text { لَا تُطُرُونِي كَمَا أَطْرَتْ النَّصَارَى ابْنَ مَرْيَمَ فَاِنَّمَا أَنَا عَبْدهُ فَقُولُوا عَبْدُ اللَّهِ وَرَسُولَهُ }
$$

Meaning: Do not praise me in excess, as Christians praised the son of Mary too much. Truly, I am only His servant, thus say: (Muhammad is) His servant and messenger. 
According to the above hadis, someone should not exaggerate in praising Prophet SAW as done by Christians towards Prophet Isa AS until it plunged them into assuming that Prophet Isa AS is the son of God (al-Qari, 1994.14:173).

If Prophet SW himself who is the last Messenger and the seal of all prophets, who is also the beloved one of Allah SWT, cannot be praised in exaggeration and excess even though Prophet SAW has been proven to spread many contributions and services to Islam and its community, it should be worse for common person who does not achieve the level of prophet and messenger such as football players who are indisputable of doing misconducts even though they are skillful in controlling the ball on the field.

\section{b. Not Hurting and Disturbing Other People}

The real Muslim is the one would not do something that can disturb or hurt other people in any form, neither in words nor actions. In the context of football watching, among which are always heard is the spectators jostling the ticket counter leading mixing, squeezing and pushing between the spectators. What more for the spectators buying the ticket in the last minute and coming to the stadium in the last minute, especially the one involving final match. In the tradition of Prophet SAW, the act of disturbing other Muslims is prohibited. Moreover, during the thronging, sometimes unnecessary words and speeches are uttered.

\section{Allah SWT said:}

Meaning: And those who disturb and hurt the male and female believers through words or actions unjust with the misconducts, then truly they have born the fault of false accusation, and done a very clear sin.

(al-Ahzab 33:58)

According to al-Jaza'iri (n.d.,3:302) the meaning of hurting the believers in the above verse is accusing them with false accusation which they have never done. The accusing person truly the one who lies and they have sinned in their life.

If it is observed in the life of Rasulullah SAW, he had never used his hands to disturb somebody in the form of hitting or others. In a hadis explaining Rasulullah SAW saying:

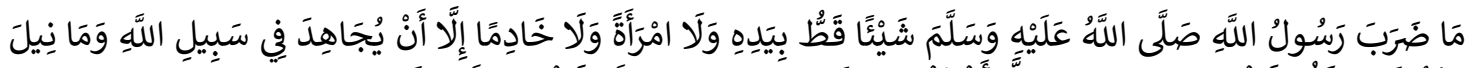

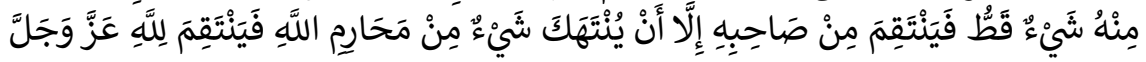

Meaning: Rasulullah SAW had ever hit anybody with his hands, an also he had never hit any woman or servant except the time when he wanted to perform jihad in the Allah's 
INTERNATIONAL JOURNAL OF ACADEMIC RESEARCH IN BUSINESS AND SOCIAL SCIENCES

Vol. 9, No. 3, March, 2019, E-ISSN: 222 2-6990 @ 2019 HRMARS

way. He SAW also did not take revenge to anything happening to him for his own interest, excepting if the matters prohibited by Allah SWT were breached, then that time he will seek revenge for Allah Azza Wajalla.

(Sahih: Muslim:4296)

The above hadis, according to al-Nawawi (1392H.15:84) is directed towards the head of family, which is allowed to hit the wife, servant and also beasts. But to not doing that is more prioritised. This means that if there is a relevant reason, the permission is given to a head of family to hit wife, servant and beasts in the purpose of education. On the other hand, disturbing or even hitting between supporters during ticket purchasing or entry into the stadium to watch football are not entirely in the purpose of education or teaching, instead it is more of getting the ticket for football watching only.

c. Not Cursing or Even Uttering Filthy Words

A Muslim cannot curse other Muslim due to a mistake or carelessness done by him either intentionally or not. That is also the same case for uttering irrelevant, obscene and dirty words. In football match, it involves spectators supporting their own team and it can be said that in each football match held, the spectators are exposed and prone to utter dirty, obscene and cursing words either to the supporters of opponent team or their own team, coaches, goalkeepers and players, when a loss happens to their supported team or due to any incidents on the field. That also goes the same when exiting the stadium in which it is prohibited to swear to the supporters of opponent team, referees, coaches, security squad and other spectators who also wish to go out from the stadium. Truly, uttering those words is forbidden in Islam. Rasulullah SAW said in the hadis narrated by Abdullah bin Mas'ud RA,

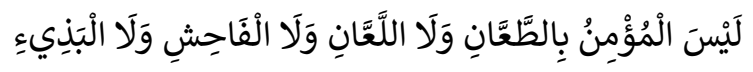

Meaning: The true believer is not the one who likes to insult, curse, speaking filthily and uttering dirty words.

(Hasan Gharib: al-Tirmizi::1900)

In a hadis narrated through Umar bin al-Khattab RA explaining:

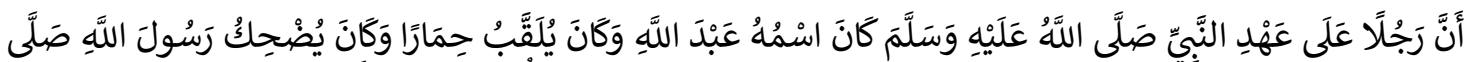

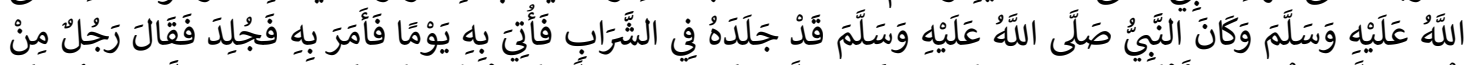

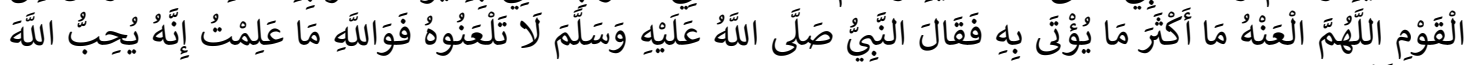

Meaning: In the time of Rasulullah SAW, there was a man named Abdullah. He was known as himar (donkey). He always caused Rasulullah SAW to laugh. Rasulullah SAW did cane him for drinking liquor. One day, he was brought before Rasulullah SAW, then 
INTERNATIONAL JOURNAL OF ACADEMIC RESEARCH IN BUSINESS AND SOCIAL SCIENCES

Vol. 9, No. 3, March, 2019, E-ISSN: 222 2-6990 ¿ 2019 HRMARS

he commanded that he was sentenced to caning. One man who was present at the event said: O Allah $O$ my God, curse him, how frequent the mistake of drinking liquor that he did. Prophet SAW said: Do not curse him. By Allah, what I know is that he is a person who loves Allah and his messenger.

(Sahih: al-Bukhari:6282)

The above hadis explains that it is not wrong to warn with proper way the mistake done by somebody, as long as the warning does not reach the level of insult. Insult is prohibited even though it is in the form of warning. This is because the sin of insulting a Muslim is the same as the sin of murdering him.

\section{d. Not Damaging Public Properties}

Property is something precious in the human life. Therefore, Islam puts that one of the main objectives in the Islamic judiciary is to take care of property so that it will not break or be damaged by irresponsible people. Islam does not prohibit the action of seeking property. Instead, what is forbidden is the way how the property is sought and how it is spent (al-Qaradawi, 1997:285). Firman Allah SWT:

Meaning: And seek by the bounties which Allah has bestowed upon you the reward and happiness of the hereafter and do not forget your portion (needs and supplies) from the world; and be good (to servants of Allah) as Allah does good to you (through His bountiful gifts); and do not do damage on the earth; Truly Allah does not like people who do damage ".

(al-Qasas 28:77)

Allah SWT said:

Meaning:... indeed Allah has allowed trade (selling) and forbidden usury....

(al-Baqarah 2: 275)

Allah SWT said:

Meaning: $O$ sons of Adam! Wear your nice clothes each time you go to the worshipping place (or perform prayer), and eat and drink, and do not go off limit; Truly Allah does not like people who go off limit.

(al-A'raf 7:31)

In consequence of that, football spectators either at the stadium or home cannot damage property, either of their own or of public or government, vehicles of opponent supporters, facilities provided at the stadium due to any frustration faced such as the loss of supported team, the referee's alleged 
INTERNATIONAL JOURNAL OF ACADEMIC RESEARCH IN BUSINESS AND SOCIAL SCIENCES

Vol. 9, No. 3, March, 2019, E-ISSN: $2222-6990$ C 2019 HRMARS

unjust decision, incompetent goalkeeper and others. This aligns with the hadis posed before this. Rasulullah SAW said in a hadis narrated through Abdullah bin Amru RA:

$$
\text { الْمُسْلِمُ مَنْ سَلِمَ الْمُسْلِمُونَ مِنْ ِلسَانِِِه وَيَِِهِ }
$$

Meaning: A real Muslim is the one whom others are safe from his tongue and hand.

(sahih: al-Bukhari:9)

People who damage others' property without any relevant reason do not only commit sin, but also are obligated to pay compensation to the victim regardless of whether it is a personal or public property, regardless of whether it is done intentionally or unintentionally. It is the view of majority of scholars ('Affanah, 2013).

e. Not Insulting, Backbiting, Scoffing and Defaming Others

Muslims cannot defame others as the action is prohibited in Islam. This includes the spectators either at the stadium or home, especially by the supporters of winning team, when their team achieves victory in a certain match. Moreover, dictionary of winning in football game does not allow the losing side to be defamed and mocked off badly, regardless of any form. Indeed, the loss and winning is not more than the custom of a play. Those who are more agile, smart in planning attack, perseverant, bolstered with tight cooperation between the members of the team, usually will gain victory. From one angle, the winning itself is a test for the winning side and their supporters, to see whether they show their gratitude to Allah SWT in celebrating the victory or ungratefulness with the bounty of Allah SWT by doing many things contradicting with the sharia along the celebration and organising of events related to the victory.

Allah SWT prohibits Muslims from mocking and defaming between each other for the weakness present among them. This is because the action of mocking and defaming others indicates the presence of hidden arrogance element, deception by own self and insulting of others. It also shows that the involved one fails to appreciate that the value of goodness in the view of Allah SWT in the real meaning depends on faith, sincerity and close relationship with Allah SWT itself. Allah SWT said:

Meaning: O people who believe! Do not one tribe (from man) scoff and defame other tribe of man, (as) the scoffed tribe might be better than them, and do not one tribe of woman scoff and defame other tribe of woman, (as) the scoffed tribe might be better than them;....

(al-Hujurat 49:11)

The goodness from the view of Allah SWT does not depend on appearance and tough body, it is also not according to titles and properties. In a hadis narrated through Abu Hurairah RA, explaining, Rasulullah SAW said:

$$
\text { إِنَّ اللَّهَ لَا يَنْظُرُ إِلَى صُوَرِكْمُ وَأَمْوَالِكُمْ وَلَكِنْ يَنْظُرُ إِلَى قُلُوبِكُمْ وَأَعْمَالِكُمْ }
$$


INTERNATIONAL JOURNAL OF ACADEMIC RESEARCH IN BUSINESS AND SOCIAL SCIENCES

Vol. 9, No. 3, March, 2019, E-ISSN: $2222-6990$ C 2019 HRMARS

Meaning: Truly Allah SWT does not look onto your appearance and properties, instead He looks onto your hearts and deeds you do.

(Sahih: Muslim: 4651)

f. Not Littering Something Eye-Irritating and Polluting the Environment

Islam is a religion of cleanliness. Therefore, Islam does not allow its people to litter something vanishing the cleanliness. For example, littering something on the road or at any place that becomes the place for gathering and meeting of Muslims that it will deface the view of the place and pollute the environment, is forbidden in Islam. This includes at the stadium when the match is commencing. Litters such as drink cans, empty plastic bottles and others are always visible around the stadium and inside it, particularly when the spectators are not satisfied with the quality of performance of a certain team, quality of judgement by the referee, which are unsatisfying and others. Actually, to express dissatisfaction towards the quality of a game, judgement by the referee, the players and others, is not by throwing water bottles, empty cans and others into the play field or outside the stadium. Instead, it can be channeled through authorities and it is them who own the right and power to take action on the complained cases. They should be given chance to do the action and not through individual punishment done by the spectators.

In Islam, not only Muslims are prohibited from littering something disturbing and hurting people on the road or gathering place, indeed they are encouraged to remove something found on the road that can disturb others' movement. The act is classified as a part of the faith itself and the shy feeling which is highly encouraged in Islam. Rasulullah SAW said in a hadis narrated through Abu Hurairah RA:

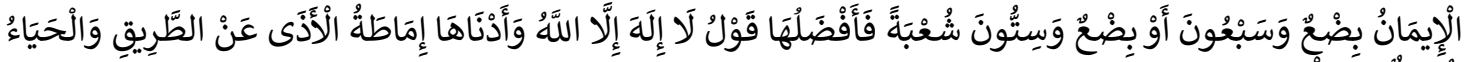

$$
\begin{aligned}
& \text { شُعْبَةٌُِْنْ الْإِيمَانِ }
\end{aligned}
$$

Meaning: Faith consists of more than 70 or 60 branches. The most *** is saying the words 'there is no God worth to be worshipped except Allah SWT' and the smallest one is removing the something disturbing the public on the road. Shyness is a part of the faith.

(Sahih: Muslim:51)

According to al-Nawawi (1392H.2:6), the things in the definition of need to be removed as it can disturb people passing by on the road, include pebbles, muds, thorns and others.

Indeed, removing something that can disturb on the road invites reward, as stated in the hadis narrated through Abu Zar RA in a Marfu' hadis: He stated: 


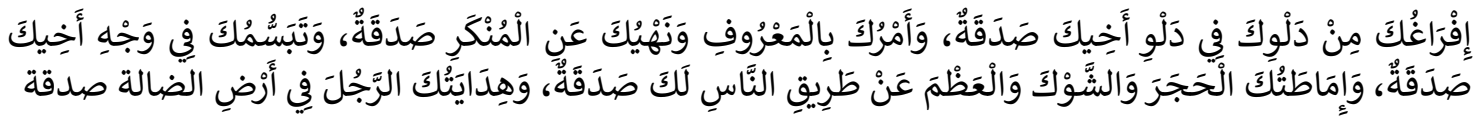

Meaning: You empty your container to fill up your brother's container brings reward. You command to do goodness and prevent unlawful acts brings reward. You smile before your brother's face brings reward. You remove something disturbing on the road like pebbles, thorns and bones, brings reward and you show the direction to somebody lost in the journey, brings reward.

(Sahih: al-Bukhari:891)

g. Not Showing an Exaggerated Sad Character and Face

Loss and winning have become a norm of football game and other games. Usually, the winning side rejoices, while the losing side becomes sad and mourns. From the aspect where sad feeling does exist, Prophet SAW himself mourns when his son named Ibrahim from his wife named Mariah alQibtiyyah died in the small age. However, that does not tarnish the status of Prophet SAW and does not contradict with the teachings of Islam as it is regarded as a nature of human that everybody can be said to possess the nature.

In a hadis narrated through Abu Hurairah RA, explaining:

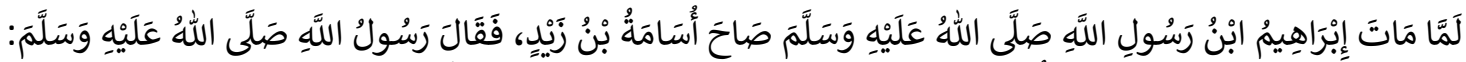

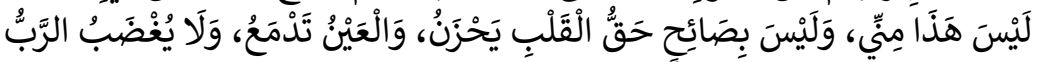

Meaning: When Ibrahim son of Rasulullah SAW died, Usamah bin Zaid screamed. Rasulullah SAW said: This act in not in my teaching and screaming people are not in the true side. Heart mourns, eyes weep and God cannot be scolded.

(Hasan: al-Hakim: 1410)

Islam prohibits its people from mourning until the level of giving up. Therefore, it is irrational for the spectators to show their sorrow until the level of giving up. What more if they display sour faces and do not want to speak with the supporters of opponent team, wife, children at home and neighbours. Sometimes, it takes a very long time. Allah SWT said:

Meaning: (You have been told about that) so that you will not be sad for anything expiring from you, and you will not rejoice (arrogantly and boastfully) for anything given to you. And (remember), Allah does not like people who are arrogant, and boastful.

(al-Hadid 57:23) 
h. Not Screaming, Whistling, Dancing and Jigging

Screaming, shouting, whistling, dancing and jigging among the football spectators are considered as something regular to do and the community is acclimatized with the actions. This can be witnessed not just by the spectators at the stadium but also the spectators at home. This act mainly comes from the west on not from the culture of Muslim and Malay community. If we look to the practice of the past ignorant people, they whistled and clapped their hands during the tawaf in Kaabah. Allah SWT said:

Meaning: And there is no prayer of them around the Baitullah except with the whistling and clapping of hands. Therefore, feel it (o you disbelievers) the torments of your infidelity.

(al-Anfal 8:35)

According to Abu Bakar al-Jaza'iri (t.th.2:40) some of the ignorant people before Islam performed tawaf while clapping hands and whistling, as done by some of tasawwuf people in this time. They dance while whistling and shouting and consider that as the hadrah of the saints.

Meanwhile, the prohibition of dancing for the men according to al-Ghamidi $(1429 \mathrm{H}: 317)$ has become an agreement among the scholars. Abu al-Wafa Ibn 'Aqil had explained that al-Qur'an clearly prohibits dance and curse those who walk with the posture of arrogant people. Dance is more than walking in the posture of arrogant people. It is an ugly act when done by beardy young people, what more if it is done by girls, joined by song rhythm and drum beating, and what more if it is involved with voices of woman and young people (al-Qurtubi,10.263).

Ibn Taimiyyah (2004, 11:599 and 604) explained that dance has never been commanded by Allah SWT, his messenger or even prominent imams of mazhab, indeed Allah SWT commanded: "You should walk humbly" and "servants of the merciful God that walk on the earth with modesty".

Allah SWT commanded Muslims to walk on earth politely. His command:

Meaning: "And be moderate in your pace while walking, and lower your voice (while speaking): Truly the ugliest voice is the voice of donkey".

(Luqman 31: 19)

Regarding the shouting during the watching of football match according to syeikh al-Ghamidi (1429:323), it is prohibited due to several factors which are:

a. Some of the shouts and screams can provoke hostility and can be monopolised by the public to encourage hostility and hatred among the Muslims. 
b. Some of the shouts and screams during the football watching imitate more of what done by the people staying in the non-Muslim countries.

c. Some of the shouts and screams contain prohibited meanings, which sometimes leading to small form of God's association act.

\section{Conclusion}

Football game involves customs and traditions and becomes a favourite activity of majority of the world population. It can be said that almost all countries in the world including Muslim countries possess their own football team competing at the national and international level. Watching of football game and match must involve ethics which need to be obeyed by every Muslim spectator to avoid unwanted incidents such as property damage, fight, utterance of bad words and environmental pollution. Those ethics are:

a. Not cursing or uttering dirty words.

b. Not damaging public property.

c. Not insulting, backbiting, scoffing and defaming others.

d. Not littering eye-irritating and polluting things.

e. Not showing exaggerated sad character and face.

f. Not shouting, whistling, dancing and jigging.

\section{Corresponding Author}

Basri Ibrahim, Jamalullail Professorial Chair, Global Wisdom Academy, Universiti Islam Malaysia, Cyberjaya, Malaysia/ Lectureur, Faculty of Islamic Contemporary Studies, Universiti Sultan Zainal Abidin, Terengganu, Malaysia..

Email: drbasr67@gmail.com.

\section{Acknowledgement}

Special thanks to the GWA, Universiti Islam Malaysia, Cyberjaya for funding the research.

\section{References}

Ali, S.M. (1998). Kurrah al-Qadam Bayna al-Masalih Wa al-Mafasid al-Syar'iyyah. Lubnan: Dar ibn Hazm.

Al-Bukhari, M.I. (1989). al-Adab al-Mufrad. Beirut: Dar al-Basya'ir al-Islamiyyah.

Al-Ghamidi, Z.S.A.H.(1429H). Haqiqah Kurrah al-Qadam. tpt.

Taymiyyah, A.T.I. (2004). Majmu' al-Fatawa. jil.11. Majma' al-Malik Fahd Li Tiba'ah al-Mashaf alSyarif.

Hafizah, Y. (2015). Faktor-Faktor Yang Mempengaruhi Salah Laku Dalam Kalangan Penyokong Pasukan Bola Sepak Di Malaysia. GEOGRAFIA Online TM Malaysian Journal of Society and Space 11 issue 13 (72 - 78) 72. 5, ISSN 2180-2491.

Khairuldin, W. M. K. F. W., Embong, A. H., Anas, W.N.I.W.N., Mohd, H. \& Ismail, D. (2018). The Application of Technology in the Dissemination of Fatwas: A Study on Religious Institutions in 
Malaysia, International Journal of Civil Engineering and Technology, 9(7), 2018, pp. 15901596.

Khairuldin, W. M. K. F. W., Anas, W. N. I. W. N., \& Embong, A. H. (2018). The Binding of Laws to Personal Opinion of Muftis in Malaysia. International Journal of Academic Research in Business and Social Sciences, 8(11), 522-529.

Al-Hakim, M.A.N. 2002. al-Mustadrak 'Ala al-Sahihayn. Beirut: Dar al-Kutub al-'Ilmiyyah.

Al-Jaza'iri, A.B. J. (n.d). Aysar al-Tafasir. Http://www.altafsir.com.

Al-Qalmuni, A.Z. (2011). Kurrah al-Qadam Wa Akhawatuha. T.pt.

Al-Qaradawi, Y. (1996). Al-Islam Wa al-Fan. Egypt: Maktabah Wahbah.

Al-Qaradawi, Y. (1997). al-Halal Wa al-Haram Fi al-Islam. Egypt: Maktabah Wahbah.

Al-Qari, M.A. 1994. Mirqah al-Mafatih Syarh Misykah al-Masabih. Jil. 14. Beirut: Dar al-Fikr.

Muslim, H. (n.d). Sahih Muslim. http://www.al-islam.com.

Al-Nawawi, M.A.Z.Y.S. (1392H). Al-Minhaj ‘Ala Syarah Sahih Muslim. Jil. 2. Beirut: Dar Ihya' al-Turath al-'Arabi.

Al-Tirmizi, M.I.S.A.I. (n.d). Sunan al-Tirmizi. http://www.al-islam.com. 